\title{
The Determinants of Liquidity Risk in Islamic Banks: A Case of Sudanese Banking Sector
}

\author{
Ahmed Nourrein Ahmed Mennawi \\ ACCA, $\mathrm{PhD}$ Candidate \\ Department of Business Administration \\ Sudan University of Science and Technology \\ Khartoum, Sudan \\ E-mail: ahmednourrein@gmail.com \\ Ahmed Ali Ahmed $P h D$ \\ Associate Professor \\ Department of Economics \\ Sudan University of Science and Technology \\ Khartoum, Sudan \\ E-mail: Dr.Ahmedbalola@gmail.com
}

\begin{abstract}
Liquidity risk either due to a surplus or serious shortage in liquidity has a significant impact to the performance and sustainability of Islamic banks. Nevertheless, there are still no common agreement on specific factors that determine the liquidity risk in Islamic banking. This study investigates the determinant factors that affect the liquidity risk of Sudanese Islamic banks. A sample of II banks has been selected for a period of 7 years $(2012-2018)$. The study is based on secondary data that analysed using Pearson correlation and multiple regression analysis for hypotheses tests. It investigated the explanatory variables of the bank's cash position (CASH), investment in short-term securities (SECA), degree of financing the assets from customers' deposits (DPAS) and bad financing and credit risk (NPL) as representatives of banks' specific factors plus one microeconomic factor which is Gross Domestic Product (GDP). The analysis found a significant and negative relation of CASH and SECA with the liquidity risk in Islamic banks. On the other hand, the results reveal that the DPAS and NPL variables have a positive relation and significant, while the GDP seen to be irrelevant to liquidity risk in Islamic bank. The importance of the study is that it touches the most significant type of risk that most of Sudanese Islamic banks face, and the data analysed covers a relatively longer period of time than similar studies for a single country. We target that the study contributes in providing decision-makers with reasonable ground for prediction and managing the liquidity risk.
\end{abstract}

Keywords: Islamic Banking, Liquidity Risk, Risk Management, Short-term Securities, Sudanese Banks.

JEL Classification: G2I, GI7, G32.

\section{Introduction}

The Islamic financing aspects - especially banking sector - witnessed a tremendous growth, from a phenomenon in mid of last century to a global view for a potential of new solutions now adays. The assets base of Islamic banks reaches US\$2.44 trillion by 2017 with an expectation of US\$ 3.8 trillion by 2023. And there is no doubt that risk management has a paramount importance in practicing of Islamic banking finance due to the uniqueness of its financing types and products characteristics in comparison with the traditional finance. Specially, Islamic banks approach is based on the principle of risk sharing to the sources and usage of funds (Ariffin et al., 2009).

Banking industry exposes to numerous types of risks on a continues basis as far as the internal and external business environment are changing. Out of these risks, the common types are liquidity, credit and market risks as they classified as financial risk, and operational risks that include internal operational (system) risk and business risks. Nevertheless, there are other risks that characterized as specific risks associated only with Islamic banking system. Whereas, they have been identified by Islamic Financial Standards Board under equity investment risk, rate of return, displaced commercial risk and Shariah noncompliance risks. Likewise, the interest rate risk is only applicable to conventional banking system. Furthermore, the volume and 
impact of such types of risks on banking industry are vary due to the nature and complexity of the bank's activities, its business process, systems, features of financing modes and competition level, as well as the external environment factors.

The latest financial crunch in 2007/208 and subsequent banking collapse - mainly in western countries - confirmed the necessity of a real management of the risks with the focus on liquidity problems. This in order to maintain a sound financial stability and performance in banks and to avoid crises in the overall economy as a consequence of severe liquidity risk. Given that, Basel Committee on Banking Supervision (BCBS) enhances many standards include a sound liquidity risk management, principles of liquidity risk management (2008), the liquidity coverage ratio - LCR (2013) and the net stable funding ratio NSFR (2014) in order to tackle the liquidity risk and its management.

While fundamentally the bank has to establish a robust and effective framework for managing the liquidity risk, a highquality liquid asset shall be maintained by bank as cushion at time of liquidity-stress (Kumar \& Yadav, 2013). Moreover, bank that has diversified sources of liquidity tends to match different timeframes of obligations which obviously creates a balancing position for the cost and benefits toward the usage and sourcing of liquidity. In addition to that bank shall apply quantitative measurements such as LCR, NSFR and cash flow forecasting to control the liquidity in different time horizons and the funding gap plus to assure adequate liquidity buffer is in place. Furthermore, Good management information systems, analysis of net funding requirements under alternative scenarios, and contingency planning consider as vital elements of liquidity management at banks of any size or operations' scope (BCBS, 2000)

Therefore, investigating the liquidity risk of Islamic banks in Sudan is significantly important as the fact that such banks play a central role in the economy and social development growth. Moreover, the annual report for 2017 that presented by the Auditor General of Sudan indicates a lack of liquidity risk management by most of the banks that the state participates to their capital. These banks failed to meet the mandatory liquidity level that determined by regulatory body in the country. It worthy to note that the Central Bank of Sudan (2018) demonstrates that the volume of financing that provided by the commercial banks to the private sector increased by $69.8 \%$ from 2017 to 2018 which represents a contribution of $23 \%$ of the total increase in the money supply. This increase accompanied by an increase in the liquid assets' ratio by addition $14.6 \%$ from 2017 to 2018 which was mainly due to the change in foreign exchange rates. By this situation, banks may struggle in their liquidity position due to mismatching the assets and liabilities sides. Furthermore, there are still a gap and need for more studies so as to cope with the development and structural reforms in the Sudanese banking industry, notably that there are few studies dealt with the context of risks that affect Islamic banks in Sudan.

This study considers important in many areas to the decision makers in banking industry as it provides a better understanding of liquidity risk and answers the questions that are related to the main factors that influence the liquidity risk in Sudanese banks. Also, it can assist to articulate suitable tools for the purpose of mitigation such risk. Moreover, we believe that this study adds contribution to the academic literature regarding the aspects of risk management which is not fully covered yet in Sudanese Islamic banking industry.

The study structures as follows: The section two provides a conceptual framework for liquidity, liquidity risk and liquidity risk management in general and in Islamic contexts, then follows by an overview of Islamic banking in Sudan. Section three gives a brief literature overview that focused on liquidity risk determinants in Islamic banking industry. Section four demonstrates the study methodology, variables characteristics and data analysis. Section five shall provide the results and discussion on the analysis findings. The final section six gives the study's conclusion and recommendations.

\section{Theoretical Background}

The context of liquidity within the financial system takes three types that include central bank liquidity, market liquidity and funding liquidity. The central bank liquidity concerns with the supply of the liquidity to the financial system in align to the monetary policy, while the market liquidity deals with the ability of business to trade an asset or commodity at short term with a low transaction cost (Nikolaou, 2009). Furthermore, funding liquidity refers to the ability of a bank to fund increases in assets and meet obligations on due course without incurring unnecessary cost (BCBS, 2000).

It is worthily to mention that the term "funding" refers to liquidity that acquires from the balance sheet liabilities of bank whereas the term "liquidity" is a broader term that usually refers to all cash and convertible resources available to the bank [International Organization of Securities Commissions (IOSCO), 2002]. Given that, the fund profile in the Islamic banks consists of two major sources, these are the current account and investment accounts holders [Islamic Financial Services Board (IFSB), 2005]. However, the practice of mixing these sources have provided Islamic banks with a cushion of liquidity that may result in distorting the performance of the banks in absence of good practice of liquidity risk management (Ali, 2004).

\section{I Liquidity Risk}

Liquidity risk is the potential loss to a bank arising from its inability either to meet its obligations or to fund increases in assets as they fall due without incurring unacceptable costs (IFSB, 2005). Accordingly, the main reason that lead the bank inherently faces liquidity risk is the maturity mismatch between the bank's assets and liabilities by transforming of short-term deposits into 
long term loans and investments. Consequently, the bank will be beyond its capacity to raise new liabilities or liquidate assets in order to repayment to depositors' demands (BCBS, 2008). In return, the excess of liquidity may also create a risk that negatively affects the profitability of the bank due to the opportunity loss.

From the balance sheet point of view, liquidity risk depends on the Islamic bank's ability to convert asset to cash quickly while on the liability side, the risk arises from the unexpected withdraw of deposits. However, Islamic banks can find it easier to reduce the mismatch between assets and liabilities by using the saving and Mudarabah deposits to finance the debt-based financing assets. Likewise, the use of restricted investment accounts to finance equity-investment contracts, while the cash and short-term financing can accommodate the regular withdrawals. (Wahyudi et al., 2015).

The IFSB (2012) provides other causes of liquidity risk as due to operational and information system failures of counterparties, or problems in a payment system resulting. Moreover, Diamond \& Rajan (20II) argued that the limited liability status gives the bank an advantage to expose itself into a liquidity risk.

An interesting part is that there are many studies (Majid, 2003; Ariffin et al., 2009; Akhtar \& Sadaqat, 20II; Islam \& Ahmed, 2017; İncekara \& Çetinkaya, 2019) claimed that Islamic banks are more exposed to the liquidity risk than in conventional banks, while other scholars (Iqbal, 2012; Gafrej \& Abbes, 2017) provided an opposite argument. Given this controversial, a balancing view see that the Islamic and conventional banks have the same number of risk factors although they are differing due to differences in the contractual system and returns' approach. (Muharam, 2013; Effendi \& Disman, 2017).

\subsection{Liquidity Risk Management}

In 2008, BCBS published the Principles for Sound Liquidity Risk Management in response to difficulties experienced by many banks due to lapses in basic principles of liquidity risk management at latest global financial crisis. This followed by a development of two standards for funding liquidity; the liquidity coverage ratio (LCR) that issued on 2013 and the net stable funding ratio (NSFR) that issued on 20I4. The LCR standard aims to ensure that a bank has an adequate stock of unencumbered high-quality liquid assets to meet its liquidity needs for a month liquidity stress scenario (BCBS, 2013, p2). While the NSFR standard requires banks to maintain a stable funding profile in relation to the composition of their assets and off-balance sheet activities (BCBS, 2014, p.I).

With regard to the main factors that create difficulty for Islamic banks in managing their liquidity (Iqbal, 20I2; Ramzan \& Zafar, 2014; Mohammad, 2015) are carefully summarized that as Sharaia restriction on assets securitization, slow development of Shariah compatible financial instruments, a lack of independent inter-Islamic bank money market, concentration on asset-backed short-to- medium term investments and the lender of last resort challenge.

Likewise, the IFSB (2015) issued a guidance note on qualitative measures for liquidity risk management on light to aforementioned BCBS liquidity standards. IFSB provides guidance and disclosure requirements on the application of the LCR and NSFR for Islamic banks. Also, IFSB (2012) developed a set of 23 principles for the Islamic banks for managing their liquidity risk. These principles shoulder the board of directors for the responsibility of setting the liquidity risk management framework, strategies, policies and level of liquidity risk tolerance. Moreover, the senior management of the Islamic banks given the role of implementation of these strategies and policies, while ensuring that liquidity is effectively and timely managed.

From another hand, Islamic banks have shown a significant development over the last four decades in improving their resilience to liquidity risk by introducing a variety of tools to manage such risk. One of these tools is the asset securitization that became increasingly an important in liquidity risk mitigation. In 2002, Liquidity Management Centre (LMC) has been established for developing a secondary liquid market based on Shariah rules.

Another significant step that taken in the Islamic financial industry is the establishment of the International Islamic Liquidity Management Corporation (IILM). The IILM launched of short-term Sukuk program in 2010 by which seen as a major breakthrough in developing Islamic financial liquidity, and to facilitate banks cross-border liquidity management, (Bello \& Saiti, 2017). By this, Islamic financial system promotes the application and use of risk sharing in the financial market that makes risk easier to manage. (Wahyudi, et al., 2015).

Many countries are started to develop Islamic liquidity management instruments that include Islamic Commercial papers, interbank investment account, commodity murabaha, sukuk, Islamic Certificates of Deposit, and Islamic Money Market (Rizkiah, 2018). Also, the commodity Murabaha and hedging through derivatives are consider part of the prime tools for liquidity management in Islamic banks. (Ayub, 2017).

\section{Literature Review}

There are considerable studies done in the area of liquidity risk management in Islamic banks. We organized these studies into (i) comparative studies, (ii) cross country studies, (iii) and specific country studies.

In two different studies conducted by Akhtar et al. (201 I); Iqbal (20I2) they examined the liquidity risk management through a comparative analysis of Islamic and conventional banks in Pakistan. Both studies measured the liquidity risk by cash to total assets ratio and they found that the return on assets (ROA) has a positive and significant relation to liquidity risk in 
Islamic bank. Also, the studies showed a positive relation for bank's size to liquidity risk in Islamic banks. Akhtar et al. (20II) concluded that conventional banks were more tend to consider investment with long-term financing, as well as they are in better profitability and liquidity risk management than in Islamic banks. In contrast, Iqbal (2012) argued that the liquidity position in Islamic banks is better than in conventional banks. Also, Muharam (2013) examined liquidity risk for 6 Islamic banks in Indonesia during the period 2007-20I I by comparing conventional and Islamic banks. The study investigated the influence of CAR, ROA, ROE, Net Interest Margin (NIM), liquidity gaps, and Risky Liquid Assets (RLA) to liquidity risk. The study revealed that conventional banks have good ability to control their capital and generate earnings by their equity that can be used to meet their short-term obligations. However, Islamic banks have good ability to generate earnings by their assets.

Moreover, in a study that covered seven countries for 20 Islamic banks and I2 conventional banks, Effendi \& Disman (2017) analysed the influence of bank-specific factors to the liquidity risk in both Islamic and conventional banks. The study applied panel data regression. Its results showed that the variables that significantly affect the liquidity risk in Islamic banks are the CAR, financial expansion (FEXP) and financing quality (FLP). While the variables that affect liquidity risk in conventional banks are FEXP, FLP, Credit Risk (NPL) and ROA. In contrast, the authors stated that the net income margin (NIM) and bank's size do not affect the liquidity risk in both types of banks, while the ROA has no effect on the Islamic banking. In addition to that, in a sample of 3 Islamic banks and 3 conventional banks in Turkey during a period of 2014-2018, İncekara \& Çetinkaya (2019) examined liquidity risk management in a comparative study that applied a panel data analysis. The liquidity risk measured by the financing gap while the independents variables divided into bank-specific variables (bank's size, NPL, ROE, ROA, CAR, and liquid asset - LA) and macroeconomic variables (GDP and inflation). The analysis results revealed that there is a negative significant effect for LA, GDP and inflation variables to liquidity risk while the NPL has a positive significant effect on Islamic banking. The relationship between NPL and LA variables to liquidity risk in conventional banks was negative and significant. The study found that the increase in liquid assets will reduce the liquidity risk exposure in both banking types, the increase in the amount of NPL decreases the liquidity risk exposure in conventional banking while increases the liquidity risk in Islamic banking, and both the ROE and ROA variables have no impact to the liquidity risk. In addition, GDP and inflation variables were insignificant in explaining liquidity risk in conventional banking.

Furthermore, following literature tackles cross-country studies for liquidity risk in Islamic banks:

Jedidia \& Hamza (2015) used a sample of 60 Islamic bank in MENA and Southeastern Asian countries. Panel data estimation was applied to investigate the determinants of Islamic bank liquidity during 2004 - 20I2. The analysis found that liquidity risk depends on bank profitability, capital adequacy ratio and investment ratio. The authors found that ROA positively affects the exposure to liquidity shortage, while the CAR and the ratio of bank's investment have significant negatively relationships with the liquidity risk. The study concluded that size of Islamic bank and GDP do not seem to be determinants of liquidity. The study recommended that Islamic bank have to improve their Profits and Losses Sharing (PLS) investment in order to reduce their liquidity risk and to reinforce Islamic instruments of liquidity risk management.

Alzoubi (2017) has analysed the determinants of liquidity risk in a study of 42 Islamic banks from 15 countries for a period from 2007 to 20I4. The author applied panel data analysis to test the independents variables impact to liquidity risk that measured by total deposits to total assets. The results showed negative correlation between liquidity risk and cash ratio, and securities held by the bank. Also, it revealed that bank size has a negative relationship with liquidity risk, as larger banks tend to have more stability and customers feel safer dealing with them. In addition to that, Bank's equity showed a negative correlation with liquidity risk as it's a stable source of funding for banks. On the other hand, there were positive relationships between high profit assets and bad finance provision to liquidity risk. In contracts, the bank size found to be with no linear relationship with liquidity risk.

Gafrej \& Abbes (2017) explored the impact of bank's specific and macroeconomic factors on banks' liquidity of 86 Islamic and IIO conventional banks across 20 countries for the period 2006 - 2013. Two measures used as proxies of banks' liquidity that are liquid assets to total assets and liquid assets to deposits and short-term funding. The study concluded that Islamic banks hold more liquidity and they can absorb the excessive withdrawal of funds better than conventional banks. Authors remarked that the liquidity in conventional banks is more delicate by internal banking factors than for Islamic banks.

Other studies conducted to examine the liquidity risk in a single country, as follows:

Ramzan \& Zafar (2014), investigated the liquidity risk management in full-fledged Islamic banks of Pakistan during 2007-20I I. The independent variables used for the study are the size of the bank, networking capital, ROE, ROA, CAR, while the liquidity risk measured by cash to total asset. The Fixed Effect Least Square Regression model is used for the analysis. The results revealed to a positive and significant relationship of bank's size with liquidity risk, whereas rest of the independent variables indicated insignificant relationship. The study remarked that strong asset base of Islamic bank supports the strengthen of liquidity control. 
Shaikh (2015) empirically investigated the determinants of liquidity risk in Islamic banks of Pakistan for a sample of 5 full-fledged Islamic banks, from 2007 to 2013 for. Liquidity risk measured by total deposit to cash, while determinants factors include deposits to capital, capital to total financing, efficiency (gross return to administrative expense), NPL and size of bank. The study indicated that deposits to total capital increases the liquidity risk and greater deposit mobilization implies greater liabilities of banks. In contracts, the increase in capital to financing decreases the liquidity risk. The study highlighted that improvement in efficiency reduces the liquidity risk.

Zaghdoudi \& Hakimi (2017) tested a sample of 10 Tunisian banks during the period from 1980 to 2015 based on panel data analysis to identify key factors of liquidity risk determinants. The liquidity risk measured by loans to total deposits, while the independent variables are credit risk, size of bank, capital adequacy, market share, economic growth and inflation rate. The study results witnessed that the key determinants of risk are bank's internal factors and it remarked that economic growth has a positive and significant effect to liquidity risk while inflation impacts negatively but not significant. In addition, the small size exposed banks to a high liquidity risk due to the low rate of supervision.

There are a few numbers of studies that conducted for liquidity risk determinants and management in the banking sector in Sudan in comparison with the banking history. Onour \& Abdo (2018) assessed the liquidity risk with a sample of 25 fullfledged Sudanese Islamic banks during the period of 2012 to 2016. The authors employed panel logit regression for the analysis. The liquidity risk measured by the extreme excess of liquidity in the bank, while the independent variables comprised of bank's specific and macroeconomic factors. The study results indicated that bank's size, and investment, are positively and statistically significant, whereas the net profit is insignificant and positively associated to liquidity risk. The study also revealed that the budget deficit variable is negatively related with liquidity risk, but insignificant. The authors argued that the insignificance of the budget deficit is a result of the government reliance in its deficit on debt financing. Moreover, they indicated that the investment portfolios in Islamic banks dominated by short term investments, and banks with larger deposits are more likely to hold more liquid assets to meet their frequent demand for cash.

Another study carried by AbdulGaniyy et al. (2017) for comparing the determinants of liquidity risk of Islamic banks in the Sudan and Malaysia banking systems. The authors collected secondary data for three banks from each country from 2004 and 20I5. The study concluded to that there is inconsistent impact of bank's specific factors of bank's size, CAR as well the GDP and Money Supply on Islamic banks' liquidity. The conclusion indicated that management efficiency is a significant determinant of liquidity risk in both banking systems.

Shamas et al. (2018) investigated the liquidity risk determinants of 7 fully-fledged Islamic banks in Bahrain over five years (2007-20II), using panel data analysis. The study found that liquidity risk of Islamic banks is positively related to bank's profitability (ROA). In contrast, credit risk (NPL) and CAR impact are negatively and significantly on liquidity risk while the size of the bank showed a negative but insignificant impact. The main limitation of this study it focused only on banks' specific factors without a consideration of any macroeconomic factors. Also, Chowdhury et al. (2019) conducted a study to investigate the relationship between bank's specific factors with liquidity risk of 6 Islamic Banks in Bangladesh from 2012 to 2016. The specific factors for bank consist of bank's size, NPL, ROA, ROE, CAR, and investment to deposit ratio (ITD). The liquidity risk measured by the cash and cash equivalent to total assets ratio. The study found that bank's size and NPL have a negative relation to liquidity risk and ROA, ROE, CAR, and ITD have a positive relationship with liquidity risk. The authors recommended that the Islamic banks have to diversify the sources of their liquidity funds, and the acknowledged the necessity of improving shariah compatible securities to provide liquidity in the market.

The above studies identified inconsistent results that clearly indicate the need for more studies on this area. The important of this study, it focuses on a single country study since the cross-country analysis do not take into consideration country specific characteristics. Also, the study includes external factor while some of the studies that conducted in a signal country did not take into consideration the external factors which may affect the liquidity risk in banks, such studies include: Ramzan \& Zafar (2014); Shaikh (2015); Shamas et al. (2018); Chowdhury et al. (2019). In addition to that, the data for this study takes a relatively loner period of 7 year comparing with other similar studies.

Previous studies' findings provide us a route to articulate the following study hypotheses:

H.I: Investment in short-term security has a negative and significant statistical effect on the liquidity risk of Islamic banks.

H.2: Funding the total assets from customers' deposits has a positive and significant statistical effect on the liquidity risk of Islamic banks.

H.3: The cash maintains by Islamic bank has a significant and negative impact to the liquidity risk.

H.4: Non-Performing loan has a positive and significant statistical impact on the liquidity risk of Islamic banks.

H.5: The gross domestic production has a negative and significant effect on the liquidity risk of Islamic banks.

In our study, we used an alpha of 0.05 for all statistical estimates and predictions. 


\section{Research and Methodology 4.I Objective and Method}

The aim of the study is to examine the relationship and impact of the five (5) independent variables on the dependent variable that is the liquidity risk. The liquidity risk is measured by the ratio of total deposits to liquid assets. The test of data done using IBM SPSS 25.0 software for providing the descriptive statistics, Pearson correlation and multiple regression analysis. Regression analysis provides the relationship and effect of independent variables to liquidity risk. The multiple regression analysis is broadly applicable for the purposes of prediction and explanation the magnitude of each dependent variable to dependent variable. It has been used in the previous studies of Akhtar et al. (201 I); Iqbal (2012); Chowdhury et al. (2019).

\subsection{The Data and Sample}

Currently, there are 37 full-fledged Islamic banks operate in Sudan that divided into 32 commercial banks and 5 especialpurpose banks. For the purpose of this study, a number of II commercial banks (30\% from all banks) have been selected in the sample with 77 observations. The sample selected on the basis of availability of the secondary data from the banks' websites for a period of 7 years from 2012 to 2018. The data obtained from the banks' annual financial reports and from the Central Bank of Sudan (CBOS) statistical reports. Since the multiple regression requires a minimum sample of 50 observations to provide statistical power of the significance testing of the result (Hair Jr. et al., 20I4) this study's sample satisfied this condition.

\subsection{Characteristics of Variables and the Model}

We have selected the following variables to structure our model for the study, as shown in table I.

Liquidity Risk (DPLQ): it is a dependent variable in this study. It measured as the ratio of total customers' deposits to liquid assets. The total deposits include the depositors' funds (current, saving and investment accounts) while the liquid assets refer to the cash and cash equivalent plus the easily convertible assets to cash (such as short-term trading securities - Sukuk). The greater the ratio the higher exposure to liquidity risk, as it indicates low liquid assets availability to meet the depositors' withdrawals at time of need. Such ratio used by Shaikh (2015); Gafrej \& Abbes (2017).

The independents variables are:

Securities (SEC): it measured by the ratio of investment in short-term securities to total bank's assets. Bank can liquidate such securities when it faces a shortage in cash so as to satisfy the depositors claims. Therefore, we expect that the higher this ratio the less liquidity risk exposure in the bank. This ratio applied by Alzoubi (2017).

Deposit to Assets (DPAS): this ratio indicates the percentage of assets which are funded by customers' deposits, and it considers inverse measure of liquidity (Milošević-Avdalović \& Kalaš, 2013) as these deposits are subject to withdrawals. The increase in this ratio indicates a higher level of liquidity risk due to significant volume of financing the assets from the customers deposits. Such ratio used by Milošević-Avdalović \& Kalaš (2013); Alzoubi (2017).

Cash Ratio (CASH): cash ratio is measured as cash and cash equivalents to total assets. It refers to liquidity buffer that maintained by bank's expectations for meeting the quick obligations. The more cash and cash equivalents at bank the less exposure to liquidity risk. Such ratio applied by Ben Jedidia \& Hamza (2015); (Alzoubi, 2017).

Nonperforming Loan (NPL): it measures the degree of bad financing and credit risk, as the higher ratio shows a significant amount of financial loss. This is due to the loss from the provided financing to bank's customers that reflects in less cash inflow, then ultimately to greater liquidity risk. The ratio is measured as a provision of customer's default (bad or doubtfully debt) to total financing. Such ratio used by Iqbal (2012); Shaikh (2015); Effendi \& Disman (2017); Shamas et al. (2018); İncekara \& Çetinkaya, (2019); Chowdhury et al. (2019).

Gross Domestic Product (GDP): it refers to the economy growth for a country. We introduced this macroeconomic factor to assess its influence on liquidity as the GDP increases during economic expansion and declines in recession's period. We assume that the increase in GDP creates a stable position that motivate the depositors to engage in long term investments rather than a short-term one. This position leads the banks to manage its liquidity and avoid the risk. This variable applied by Jedidia \& Hamza (2015); AbdulGaniyy et al. (2017). 
Below table shows the summary of the study's variables:

Table I. The dependent and independents variables.

\begin{tabular}{lllll}
\hline Variable & Symbol & Proxies & Type of Variable & $\begin{array}{l}\text { Expected } \\
\text { Sign }\end{array}$ \\
\hline Liquidity Risk & DPLQ & Total Deposits / Liquid Asset & Dependent & NA \\
\hline Securities & SEC & Short-term Securities/Total Asset & Independent & - \\
\hline Assets & DPAS & Customers' Deposits to Total Assets & Independent & + \\
\hline Cash & CATA & Cash to Total Assets & Independent & - \\
\hline Loan Quality & NPL & Nonperforming to Total Financing & Independent & + \\
\hline Economic Cycle & GDP & Gross Domestic Production Rate & Independent & - \\
\hline
\end{tabular}

Accordingly, the model has been formulated for this study as follows:

DPLQit $=a+\beta$ I SECit $+\beta 2$ DPASit $+\beta 3$ CATAit $+\beta 4$ NPLit $+\beta 5$ GDPit $+\varepsilon$

Whereas:

a : the intercept

$\beta I-\beta 6$ : the regression coefficient of independent variables.

$\mathrm{i} \& \mathrm{t}$ : They refer to the banks in the sample and the period covers the study, respectively.

$\varepsilon:$ standard error.

\section{Data Analysis and Discussion \\ 5.I Descriptive Statistics}

The descriptive statistics aims to present the data in a useful way that provides a ground for an interpretation. Table 2. shows that the average DPLQ is 20I.55\% which indicate that banks' liquid assets can cover half of all customers deposits, with a significant variation between the sampled banks. The mean for SECA is $14.77 \%$ (with a minimum of $3 \%$ and maximum of 71.34\%) which implies that a significant portion banks' resources are in form of short-term securities, which in return support the liquidity position. The banks. DPAS ratio has an average of $69.65 \%$ which explains that the banks in Sudan are heavily using customers deposits to finance their business rather than shareholders contribution. With CATA average of $26.27 \%$ (standard deviation of 10.68), we see that 95\% of banks have a cash buffer lies between $4.9 \%$ to $47.6 \%$. In regard to NPL, the average is $5.31 \%$ which is higher than the regulator threshold (i.e. $4 \%$ ), in addition to that a large difference in the ratio is seen as the minimum is $1.15 \%$ and the maximum is $22.38 \%$. The standard deviation in the table shows that the variables' dataset is very closed to their mean and there is less risk involved in the sample's data.

Table 2. Descriptive statistics

\begin{tabular}{llllll}
\hline Variable & N & Minimum & Maximum & Mean & Std. Deviation \\
\hline DPLQ & 77 & 35.47 & 528.97 & 201.55 & I00.33 \\
\hline SECA & 77 & .03 & 71.34 & 14.77 & 12.44 \\
\hline DPAS & 77 & 28.36 & 103.90 & 69.65 & 16.95 \\
\hline CATA & 77 & I 1.03 & 71.29 & 26.27 & 10.68 \\
\hline NPL & 77 & 1.15 & 22.38 & 5.31 & 4.04 \\
\hline GDP & 77 & 2.40 & 7.00 & 4.95 & 1.60 \\
\hline Valid N (listwise) & 77 & & & & \\
\hline
\end{tabular}

\subsection{Correlation Analysis}

Table 3. shows the Pearson's correlation estimates. It shows that the relationship between the dependent variable and independent variables. Both, SECA and CATA have a negative correlation and highly significant at 99\% significant level $[(\mathrm{r}=$ $.580, \mathrm{p}<.00 \mathrm{I})$ and $(\mathrm{r}=-.44 \mathrm{I}, \mathrm{p}<.00 \mathrm{I})$ respectively] with the liquidity risk, while the DPAS has a positive correlation and highly significant at $99 \%$ significant level $(\mathrm{r}=.537, \mathrm{p}<.00 \mathrm{I})$ with liquidity risk. A weak positive correlation and significant at $95 \%$ significant level $(\mathrm{r}=.260, \mathrm{p}=.023)$ is shown by the NPL with exploratory variable. The microeconomic metric, GDP shows a little negative correlation and not significant $(\mathrm{r}=.09, \mathrm{p}=.435)$ to liquidity risk. 
The correlation matrix shows that there is no multicollinearity between the independent variables, since the maximum relationship found between SECA and DPAS $(\mathrm{r}=.444)$ that within the normal range (i.e. $\mathrm{r}<.8$ ).

Table 3. Pearson's Correlations Estimates

\begin{tabular}{|c|c|c|c|c|c|c|}
\hline & DPLQ & SECA & DPAS & CATA & NPL & GDP \\
\hline DPLQ & I & & & & & \\
\hline SECA & $-.580^{\text {稵 }}$ & I & & & & \\
\hline DPAS & $.537^{2 x+x}$ & -0.444 & $\mathrm{I}$ & & & \\
\hline CATA & $-.44 I^{\text {新 }}$ & -0.179 & 0.146 & $\overline{\mathrm{I}}$ & & \\
\hline NPL & $.260^{4 x}$ & -0.049 & 0.053 & -0.162 & $\mathrm{I}$ & \\
\hline GDP & -0.09 & -0.134 & -0.036 & 0.107 & -0.03 & $\mathrm{I}$ \\
\hline
\end{tabular}

\subsection{The Regression Analysis and Coefficient Explanation}

Table 4 . shows the regression model summary. It indicates that the correlation coefficient of $\mathrm{R}=0.888(88.8 \%)$ that suggests the strength of the association between liquidity risk with and independent metrics in the model. The coefficient correlation square (or coefficient of determination) R2 measures the proportion of variability in the dependent variable that explained by independent variables. The model shows that R2 is 0.789 which indicates that $78.9 \%$ variation in liquidity risk explained by SEC, DPAS, CATA, NPL and GDP predictors. Accordingly, we assume that there is a greater the explanatory power of the regression equation and the better the prediction of the dependent variable. From other hand, the Adjusted R2 is a modified measure of the coefficient of determination that takes into consideration the sample size and the number of independent variables that build the regression model. The Adjusted R2 estimates that $77.4 \%$ of the liquidity risk is explained by the aforementioned independent variables.

The F-statistics of 53.086 and its associated significant value of $\mathrm{p}<0.00 \mathrm{I}$ which conclude that our model results in significantly better prediction of liquidity risk. Moreover, the Durbin-Watson (D-W) test gives a value of $\mathrm{I} .797$ which is higher than upper critical value $(\mathrm{dU}=\mathrm{I} .772)$ of the $\mathrm{D}-\mathrm{W}$ significant table with $5 \%$ significance points. Thus, there is no autocorrelation problem.

Table. 4. The Regression Model Summary

\begin{tabular}{|c|c|c|c|c|c|c|c|c|c|}
\hline \multirow{2}{*}{$\begin{array}{l}\text { Mode } \\
1\end{array}$} & \multirow{2}{*}{$\mathrm{R}$} & \multirow[t]{2}{*}{$\mathrm{R} 2$} & \multirow[t]{2}{*}{ Adj R2 } & \multirow{2}{*}{$\begin{array}{l}\text { Std. Error of } \\
\text { the Estimate }\end{array}$} & \multicolumn{5}{|c|}{ Change Statistics } \\
\hline & & & & & $\begin{array}{l}\text { R2 } \\
\text { Change }\end{array}$ & $\begin{array}{l}\mathrm{F} \\
\text { Change }\end{array}$ & dfI $\quad$ df2 & $\begin{array}{ll}\text { Sig. } & \mathrm{F} \\
\text { Change } & \end{array}$ & $\begin{array}{l}\text { Durbin- } \\
\text { Watson }\end{array}$ \\
\hline I & $.888 a$ & .789 & .774 & 47.68366 & .789 & 53.086 & $7 \mathrm{I}$ & .000 & 1.797 \\
\hline \multicolumn{10}{|c|}{ a. Predictors: (Constant), GDP, NPL, DPAS, CATA, SECA } \\
\hline \multicolumn{10}{|c|}{ b. Dependent Variable: DPLQ } \\
\hline
\end{tabular}

Table 5. shows the coefficients for the regression. The unstandardized coefficient indicates the change in the dependent variable with a unit increment in the independent variable. It is the a meaningful to be used to find out what the effect of changes in independents variables on the dependent variable.

The regression results indicate that all bank's specific variables, SECA, CATA, DPAS and NPL highly significant to liquidity risk in Islamic banks in Sudan as SECA, CATA and DPAS have p-values $<0.001$, while NPL has $\mathrm{p}$-value $<0.05$. In contrary, GDP variable shows that it does not have an impact to liquidity risk of Islamic banks in Sudan. Its $\mathrm{p}$-value $=. \mathrm{I} 43$ which is higher than $5 \%$ level of confidence.

By these results, the study demonstrate that all hypotheses are accepted except hypothesis H05. that reveals to no impact of the Gross Domestic Product factor to liquidity risk in Islamic banks in Sudan

The multicollinearity diagnostics test reveals that there is no inflation in the variances of the parameters estimates. The test results show that to VIF values lie betweenI.036 and I.30I which is lower than the suggested thresholds by Hair Jr. et al. (20I4) (VIF values of even 3 to 5) or the rule of thumb for VIF less than IO. Therefore, this confirms that there is no multicollinearities problem among the variables. 
Accordingly, the model for predicting the liquidity risk determinant in Islamic banks in Sudan shown as follows:

Liquidity Risk $($ DPLQ it $)=254.205-4.164$ SECit + 2.250 DPASit - 5.260 CATAit + 3.002 NPLit - 5.I62 GDPit ...(2)

Table 5. The Regression Coefficients Estimates.

\begin{tabular}{|c|c|c|c|c|c|c|c|}
\hline & \multicolumn{2}{|c|}{$\begin{array}{l}\text { Unstandardized } \\
\text { Coefficients }\end{array}$} & \multirow{2}{*}{$\begin{array}{l}\text { Standardized } \\
\text { Coefficients } \\
\text { Beta }\end{array}$} & \multirow[t]{2}{*}{$\mathrm{t}$} & \multirow[t]{2}{*}{ Sig. } & \multicolumn{2}{|c|}{ Collinearity Statistics } \\
\hline & $\bar{B}$ & Std. Error & & & & Tolerance & VIF \\
\hline (Constant) & 254.205 & 39.025 & & $6.5 \mathrm{I} 4$ & .000 & & \\
\hline SECA & -4.164 & .502 & -.516 & -8.302 & .000 & 0.768 & I.30I \\
\hline DPAS & 2.25 & .364 & .380 & $6.18 \mathrm{I}$ & .000 & 0.786 & 1.272 \\
\hline CATA & -5.26 & .532 & -.560 & $-9.88 \mathrm{I}$ & .000 & 0.925 & $\mathrm{I} .08 \mathrm{I}$ \\
\hline NPL & 3.002 & 1.379 &. $\mathrm{I2I}$ & 2.177 & .033 & 0.965 & 1.036 \\
\hline GDP & -5.162 & 3.485 & -.082 & $-\mathrm{I} .48 \mathrm{I}$ & .143 & 0.962 & 1.040 \\
\hline
\end{tabular}

\subsection{Discussion}

In accordance to the findings, all bank's specific variables are significant in determining the liquidity risk of Sudanese banks. While the unexpected result attached to the macroeconomic factor (GDP) that shows insufficient impact. The associated coefficients show that a decrease of $4.164 \%$ in liquidity risk is observed due to $1 \%$ increase in the short-term securities, while the liquidity risk decrease by $5.26 \%$ at the increase of cash and cash equivalent by $\mathrm{I} \%$. Such results indicate the fact that cash is an immediate option to settle depositors' claims while at time of liquidity shortage the bank can use the short-term securities to mitigate the liquidity position. Islamic banks in Sudan maintain a considerable portion of liquidity in term of short-term securities (Sukuk) for both liquidity risk mitigation option and improve the profitability status. This result proves the first and second hypothesises and it in line with the result that found by Alzoubi (2017). The bank management and policy makers need to regulate and balance the status of cash buffer and liquid assets to match the duration of obligations. This will support the banks' performance and liquidity management.

The results also reveal that financing the bank's assets from customers' deposits is positively and statistically significant to liquidity risk, which indicate that an increase of I\% of bank's assets that funded from customers' deposit leads to an increase of $2.25 \%$ in liquidity risk. This result demonstrates that an increase in using of depositors' funds to finance assets with different maturity leads to liquidity problem unless a high matching principle of maturity being in right place and also may increase the cost of funding.

Moreover, the results show that nonperforming loan is positively correlated and significant to liquidity risk, as far as its change by $\mathrm{I} \%$ results in a change in liquidity risk by $3.0 \%$. This result confirmed by the studies that conducted by Alzoubi (2017); İncekara \& Çetinkaya (2019). By contrast, some empirical studies show that NPL has a negative and significant impact to liquidity risk, such as Iqbal (2012); Shamas et al. (2018). The nonperforming financing is a direct reflection of banks' weak decisions and control toward the financing, especially the participatory financing modes (Musharakah and Mudaraba). The banks' policy makers need to maintain a high-quality credit management and effective creditworthiness shall be applied in order to mitigate the financing loss.

Finally, the GDP does not have impact as a determinant factor to liquidity risk of Islamic banks in Sudan. This finding consistent with that reported by Ben Jedidia \& Hamza (2015); Gafrej \& Abbes (2017); AbdulGaniyy, et al. (2017).

\section{Conclusion}

Liquidity risk considers a paramount matter among other types of risks that Islamic banks in Sudan face. Therefore, this study empirically investigates the determinant factors that affect aforementioned risk within a sample of II Islamic banks, for a period of 7 years $(2012-2018)$. We used Pearson's correlation and multiple regression analysis to determine the relationships and degree of influences of explanatory variables to liquidity metric.

The test of hypothesis reveals that cash held by bank, investment in short-term securities (sukuks), degree of financing the assets from customers' deposits, and credit risk management have a significant impact on liquidity risk in Islamic banks. While, the GDP as a metric for macroeconomic seems to be irrelevant to liquidity risk in Islamic bank. Moreover, the findings show that keeping a cash buffer, short-term securities that easily liquidated and enhancing the quality of assets and financing by Islamic banks lead to mitigate the liquidity risk to a reasonable level. 
In addition to the findings that given in this study, several outcomes appeared accordingly. Islamic banks in Sudan seems to be relied on investing into short-term projects rather than long run investment alternatives such as Musharaka and Mudharaba. That explained by maintaining high level of cash buffer and liquid assets in banks in order to mitigate any withdrawals by depositors. In addition to that, the banks in Sudan mainly depend on depositors' funds in contrast to shareholders' equity fund. Obviously, this increase the burden to unrestricted investment account holders especially the nonperforming loan (financing) percentage seems to be high in the sampled banks. Moreover, using the depositors' funds to finance banks' assets shall be in line with the liquidity management policy and strategy that enable the banks to match different funds' sources with the appropriate usage and plan. This has been shown by the study as it has a significant implication to the liquidity risk context.

The study recommend that banks management shall encourage the depositors to use their funds into medium and long terms investments (i.e. Musharakah and Mudarabah) this will improve the banks' liquidity management. Furthermore, the banks need practically to use the quantitative and qualitative tools periodically for assessing and managing their assets and liabilities. We encourage to establish a liquidity resilience and sustainability plan as part of the banks overall strategic plans, as this shall promote managing both short-term and long-term liquidity positions along with a balancing situation with other performance objectives. Also, it is necessity for policy makers to develop Islamic money markets to act actively in dealing with different Shariah compatible securities that can assist in providing liquidity to banks when they need it and support the mobility of funds. Moreover, conducting further studies in the area of liquidity management and performance is highly recommended by including other internal-bank and external factors, as well as to other types of risk that affect the Islamic banks.

\section{References}

AbdulGaniyy, A., Zainol, Z., \& Ahmad, N. H. (2017). Determinants of liquidity risk in dual and fully Islamic banking systems: Evidence from Malaysia and Sudan. Asian Journal of Multidisciplinaty Studies, 5(I), 90-99.

Akhtar, M. F., Ali, K., \& Sadaqat, S. (20I I). Liquidity risk management: a comparative study between conventional and Islamic banks of Pakistan. Interdisciplinary journal of research in business, $I(\mathrm{I}), 35-44$.

Ali, S. S. (2004, February). Islamic modes of finance and associated liquidity risks. In conference on Monetary Sector in Iran: Structure, Performance \& Challenging Issues, Februaty, Tehran, Iran.

Alzoubi, T. (2017). Determinants of liquidity risk in Islamic banks. Banks and Bank Systems, I2(3), I42-I47.

Ariffin, N. M., Archer, S., \& Karim, R. A. A. (2009). Risks in Islamic banks: Evidence from empirical research. Journal of Banking Regulation, IO(2), I53-I63.

Ayub, M. (2017). Liquidity Management by Islamic Banks: An Issue or a Contrivance for Risk-Free Returns, Journal of Islamic Business \& Management, 7(I),I-I0.

Basel Committee on Banking Supervision. (2000). Sound Practices for Managing Liquidity in Banking Organisations, Basel, Switzerland. Retrieved from https://www.bis.org/publ/bcbs69.pdf.

Basel Committee on Banking Supervision-principles. (2008). Principles for Sound Liquidity Risk Management \& SupervisionBasel, Switzerland. Retrieved from https://www.bis.org/publ/bcbsI44.pdf.

Basel Committee on Banking Supervision. (2013). Basel III: The Liquidity Coverage Ratio and liquidity risk monitoring tools", Basel, Switzerland. Retrieved from https://www.bis.org/publ/bcbs238.pdf.

Basel Committee on Banking Supervision. (20I4). Basel III: the net stable funding ratio, BCBS, Basel, Switzerland. Retrieved from https://www.bis.org/bcbs/publ/d295.pdf.

Bello, N., Hasan, A., \& Saiti, B. (2017). The mitigation of liquidity risk in Islamic banking operations. Banks \& bank systems, I2(3),I54-I65.

Central bank of Sudan. (2018). Annual Report, 58. Retrieved from https://cbos.gov.sd/en/content/ annual-report-2018.

Chowdhury, M. M., Zaman, S. \& Alam, M. A. (2019). Liquidity Risk Management of Islamic Banks in Bangladesh, International Journal of Business and Technopreneurship, 9(1),37-48.

Diamond, D. W., \& Rajan, R. G. (20II). Fear of fire sales, illiquidity seeking, and credit freezes. The Quarterly Journal of Economics, I26(2), 557-59I.

Effendi, K. A., \& Disman, D. (2017). Liquidity Risk: Comparison between Islamic and Conventional Banking. European Research Studies, 20(2), 308-318.

Gafrej. O. \& Abbes. M. B. (2017). Liquidity Determinants of Islamic and Conventional Banks. Journal of Islamic Banking and Finance, 34(2),44-61.

Hair Jr. J. F., Black. W. C., Babin. B. J. \& Anderson. R. E. (2014). Multivariate Data Analysis), 7th ed. Pearson Education Limited 2014, UK. London. Retrieved from www.pearsoned.co.uk.

İncekara, A., \& Çetinkaya, H. (2019). Liquidity Risk Management: A Comparative Analysis of Panel Data Between Islamic and Conventional Banking in Turkey. Procedia Computer Science, I58, 955-963.

International Organization of Securities Commissions. (2002). Sound Practices for the Management of Liquidity Risk at 
Securities Firms", Technical Committee Report,I-3I.

Iqbal. A. (2012). Liquidity Risk Management: A Comparative Study between Conventional and Islamic of Pakistan, Global Journal of Management and Business Research, I2(5),54-64.

Islam. A., Farooq. M., and Ahmad. A. (2017). Factors Affecting Liquidity Position of Islamic Banks, City University Research Journal, Special Issue: AIC, Malaysia, 27-36.

Islamic Financial Services Board - IFSB - I. (2005). Guiding principles of Risk Management for Institutions (Other than Insurance Institutions) Offering Only Islamic Financial Services. Kuala Lumpur, Malaysia. Retrieved from https://www.ifsb.org/published.php.

Islamic Financial Services Board - IFSB - I2. (2012). Guiding Principles on Liquidity Risk Management for Institutions Offering Islamic Finance (Excluding Islamic Insurance (Takaful) Institutions and Islamic Collective Investment Schemes), Kuala Lumpur, Malaysia. Retrieved from https://www.ifsb.org/published.php.

Islamic Financial Services Board - GN6 (2015). Guiding Note on Quantitative Measures for Liquidity Risk Management for Institutions Offering Islamic Finance (Excluding Islamic Insurance (Takaful) Institutions and Islamic Collective Investment Schemes), Kuala Lumpur, Malaysia. Retrieved from https://www.ifsb.org/published.php\#GN.

Jedidia, K. B., \& Hamza, H. (2015). Determinants of liquidity risk in Islamic banks: A panel study. Islamic Management and Business, 2(2), I37-I46.

Kumar, M., \& Yadav, G. C. (2013). Liquidity risk management in bank: a conceptual framework. AIMA journal of management \& research, 7(2), 2-I2.

Majid, A. (2003). Development of Liquidity Management Instruments: Challenges and opportunities, International Conference on Islamic Banking: Risk Management, Regulation and Supervision, Jakarta-Indonesia. Sept 30 - to October 3, 2003, I-24.

Milošević-Avdalović, S., \& Kalaš, B. (2016). Determinants of deposit potential as inverse liquidity indicator of commercial banks in Serbia. Industrija, 44(3), 61-76.

Mohammed. S. (2015). Liquidity Risk Management in Islamic Banks: A Survey, Afro Eurasian Studies, I(2),215-230.

Muharam. H. (2013). The Influence of Fundamental Factors to Liquidity Risk on Banking Industry: Comparative Study between Islamic Bank and Conventional Bank in Indonesia" (October 12, 2013). Conference in Business, Accounting and Management (Cbam) 2012 I (2), 359-368, Unissula, Semarang Indonesia.

Nikolaou. K. (2009). Liquidity (risk) concepts definitions and interactions, working paper series no. 1008, I-70, European Central Bank. Retrieved from http://ssrn.com/abstract_id=I333568.

Onour. I. A. \& Abdo. M. M. (2018). Liquidity Risk Management in Islamic Banks: Evidence from Sudan. Retrieved from https://www.researchgate.net/publication/32830607I.

Ramzan. M. \& Zafar. M. I. Z. (2014). Liquidity Risk Management in Islamic Banks: A Study of Islamic Banks of Pakistan, Interdisciplinary Journal of Contemporary Research in Business, 5(12),199-216.

Rizkiah, S. K. (2018). Liquidity Management in Islamic Banking: Issues and Challenges, Tazkia Islamic Finance and Business Review,I2(2),I3I-I52.

Shamas, G. S., Zairani. Z., \& Zairy. Z. (2018). The Impact of Bank's Determinants on Liquidity Risk: Evidence from Islamic Banks in Bahrain, Journal of Business \& Management, 6(I), I-22.

Shaikh. S. A. (2015). Panel Data Estimation of Liquidity Risk Determinants in Islamic Banks: A Case Study of Pakistan, MPRA Paper 68749,I-I2, University Library of Munich, Germany.

Thomson Reuters. (2018). Islamic Finance Development Report 2018 - Building Momentum report. Retrieved from https//ceif.iba.edu.pk/pdf/Reuters-Islamic-finance-development-report2018.pdf.

Van Greuning, H., \& Iqbal, Z. (2008). Risk Analysis for Islamic Banks, The International Bank for Reconstruction and Development, The World Bank, I8I8 H Street NW, Washington, DC.

Wahyudi. I., Rosmanita. F., Prasetyo. M. B., Putri. N. I. S., (2015). Risk Management for Islamic Banks: Recent Developments from Asia and Middle East, Published by John Wiley \& Sons Singapore Pte. Ltd.

Zaghdoudi. K. \& Hakimi. A. (2017). The Determinants of Liquidity Risk: Evidence from Tunisian Banks, Journal of Applied finance and Banking, 7(2),7I-8I. 


\section{Appendix}

List of Islamic Sudanese Banks Wherease Data Collected from Their Annual Reports:

\begin{tabular}{llllll}
\hline No & Bank name & Establishment & No & Bank name & Establishment \\
\hline I & Omdurman National Bank & I993 & 7 & Export Development Bank & I98I \\
\hline 2 & Blue Nile Mashreq Bank & 2003 & 8 & Tadamon Islamic Bank & I98I \\
\hline 3 & Al Shamal Islamic Bank & I990 & 9 & Farmer's Commercial Bank & I999 \\
\hline 4 & Faisal Islamic Bank-Sudan & I978 & I0 & $\begin{array}{l}\text { Aljazeera Sudanese Jordanian } \\
\text { Bank }\end{array}$ & 2006 \\
\hline 5 & Bank of Khartoum & I9I3 & II & Investment Bank & I997 \\
\hline
\end{tabular}

\section{Copyrights}

Copyright for this article is retained by the author(s), with first publication rights granted to the journal. This is an open-access article distributed under the terms and conditions of the Creative Commons Attribution license (http://creativecommons.org/licenses/by/4.0/). 